\title{
Site U1323
}

\author{
Expedition 308 Scientists $^{2}$
}

\section{Chapter contents}

Background and objectives........... 1

Summary of operations............. 2

Downhole measurements............ 2

Figures.................6

Table ................... 13

${ }^{1}$ Expedition 308 Scientists, 2006. Site U1323. In Flemings, P.B., Behrmann, J.H., John, C.M., and the Expedition 308 Scientists, Proc. IODP, 308: College Station TX (Integrated Ocean Drilling Program Management International, Inc.). doi:10.2204/iodp.proc.308.107.2006

'Expedition 308 Scientists' addresses.

\section{Background and objectives Geological setting of Mars-Ursa Basin}

The geological framework of Mars-Ursa Basin is treated in detail in the "Site U1322" chapter. The reader is referred to this chapter regarding detailed background information and a more extensive compilation of the data available before drilling operations began. This also applies to the figures and tables contained in the chapter (see Figs. F1, F2, F3, F4 in the "Site U1322" chapter; Table T1 in the "Site U1322" chapter).

\section{Overview of seismically mapped surfaces}

Site U1323 is the middle location of the three sites drilled along an east-west transect in Ursa Basin (see Figs. F2, F3 in the "Site U1322" chapter). Site U1323 is located in $1262 \mathrm{~m}$ water depth and was originally scheduled for coring, wireline logging, and logging-while-drilling/measurement-while-drilling (LWD/MWD) operations to a terminal depth (TD) of 358 meters below seafloor (mbsf), $20 \mathrm{~m}$ above the top of the Blue Unit (Fig. F4 in the "Site U1322" chapter). The site is located within Mississippi Canyon Lease Block 898. Eight seismic surfaces are mapped along the Ursa Basin transect (Fig. F1; see also Fig. F4 and Table T1 in the "Site U1322" chapter). Among those, seismic Reflectors S10, S20, S30, and $\mathrm{S} 80$ are regional surfaces that span all three drill sites. Seismic Reflector S10 at $1731 \mathrm{~ms}$ two-way traveltime (TWT), or $33 \mathrm{mbsf}$, is probably the base of the hemipelagic drape sediments. Seismic Reflector S20 (1812 ms TWT; 97 mbsf) separates distal levee muds from the underlying fine-grained clastics of the eastern Southwest Pass Canyon levee. The upper and lower parts of this packet of strata seem seismically well defined, but the middle part exhibits disturbance and disruption, possibly due to slumping. Seismic Reflector S30 (1938 ms TWT; $197 \mathrm{mbsf}$ ) is a detachment surface that underlies one of the mass transport deposits (MTDs). Seismic Reflector S30 can be easily traced from Site U1324 farther to the west (Fig. F4 in the "Site U1322" chapter). In the immediate vicinity of Site U1323 seismic Reflector S30 forms the base of a series of MTDs (Fig. F1). Between seismic Reflectors S30 and S50-1323 (2068 ms TWT; $305 \mathrm{mbsf}$ ), the reflection character is complex.

The top of the Blue Unit (seismic Reflector S80) is delineated by a weak negative polarity reflector of irregular geometry that can be traced regionally (Fig. F1; see also Fig. F4 in the "Site U1322" chapter). 


\section{Local summary of borehole expectations}

Latest Pleistocene to Holocene sedimentation at Site U1323 is characterized (from youngest to oldest) by a hemipelagic drape, underlain by a packet of muddy sediments of distal levee nature, in part containing MTDs. Below this horizon, the heavily disturbed deposits of the eastern levee of Southwest Pass Canyon are in turn underlain by a body of sediments belonging to the eastern levee of Ursa Canyon, close to the core of the canyon fill. The Ursa Canyon levee deposits locally cut into the underlying sand-dominated Blue Unit (Fig. F1; see also Fig. F4 in the "Site U1322" chapter).

\section{Drilling objectives}

The primary drilling objectives at this site were the following:

- Characterize porosity and other key physical properties as a function of depth by means of correlating the LWD/MWD data with those and core observations at Sites U1322 and U1324. Derive a model to account for gradients in density/porosity and relation to overburden for the Ursa Basin transect.

- Use LWD/MWD data to optimize correlation of lithostratigraphic units between Sites U1322 and U1324 and aid development of a two-dimensional depositional and sedimentary facies model for the Ursa Basin transect.

- Monitor evolution of downhole pressure in preparation of possible future coring.

To achieve these objectives, a dedicated LWD/MWD hole (Hole U1324A) was to be drilled to a projected TD of 358 mbsf. Drilling was halted at 247 mbsf and the hole abandoned after $>1.5 \mathrm{~m}$ sand intervals were penetrated repeatedly and because of a sudden increase in annular pressure while drilling (APWD) on the order of 150 psi at 207 mbsf. For a detailed description, see "Operations." Despite this, a complete set of LWD/MWD data was collected to TD of 247 mbsf for correlation with core, wireline logging, and LWD/MWD data from Sites U1322 and U1324.

\section{Summary of operations}

\section{Hole U1323A}

A summary of operations in Hole U1323A can be found in Table T1, and a more comprehensive description of MWD/LWD operations can be found in "Downhole measurements." A beacon was deployed at Site U1323 at $1854 \mathrm{~h}$ on 15 June 2005. Hole U1323A was spudded at $2025 \mathrm{~h}$ as the driller tagged the seafloor at 1271.0 meters below rig floor (mbrf) (precision depth recorder $=1278.4 \mathrm{mbrf}$ ). The vibration-isolated television (VIT) camera was recovered and MWD drilling advanced to 206 mbsf. A sand layer, $\sim 1.5 \mathrm{~m}$ in thickness (as interpreted from natural gamma ray resistance data from the MWD bit), was detected at 204 mbsf. Simultaneously, a 150 psi jump over background drilling pressure in the pressure-while-drilling (PWD) log was observed. A residual backpressure of 150 psi was also observed by the driller when he shut down the mud pumps. We pumped $50 \mathrm{bbl}$ of $10.5 \mathrm{ppg}$ mud in the hole and noted that the backpressure went to zero. When this mud was displaced with seawater, the overpressure returned. The pipe was filled with $110 \mathrm{bbl}$ of 10.5 ppg mud and a wiper trip was made to $51.1 \mathrm{mbsf}$ and back to 204.6 mbsf. The overpressure remained, and it was decided to continue to drill ahead at a very low rate of penetration (ROP), gradually increasing to $30 \mathrm{~m} / \mathrm{h}$, with "pumping and dumping" $10.5 \mathrm{ppg}$ mud. At 242 mbsf, a rapid drop in gamma radiation, suggestive of a second sand interval, was observed in the data. At this point, it was decided that to maximize the amount of science and to conserve mud, we should move to the location of Site U1324 (BP Block MC 897) and plug and abandon Hole U1323A. We displaced the hole with $73 \mathrm{bbl}$ of $13.5 \mathrm{ppg}$ mud. The VIT camera was deployed and the top of the hole was observed to confirm that there was no flow. A free-fall funnel was deployed and inspected again with the VIT camera. We reentered Hole U1323A at $0300 \mathrm{~h}$ on 17 June. An obstruction or hole collapse at 140 mbsf prevented further penetration into the hole, and Hole U1323A was displaced with $31.8 \mathrm{bbl}$ of $14.0 \mathrm{ppg}$ cement that applied a cement plug from 140 to 40 mbsf. The drill string was then recovered, clearing the seafloor at $0550 \mathrm{~h}$ and the rotary table at $1010 \mathrm{~h}$ on 17 June.

\section{Downhole measurements}

Site U1323, located between Sites U1322 and U1324, was a dedicated LWD/MWD site. The principal objectives at this site were to characterize key physical properties and compare and correlate with Sites U1322 and U1324.

\section{Logging while drilling and measurement while drilling}

\section{Operations}

Operations in Hole U1323A used the same LWD/ MWD tool configuration, bottom-hole assembly, and procedures as Site U1322 (see "Operations" in the "Site U1322" chapter). The hole was started using a rapid jet-in penetration and pump rates of $\sim 12$ strokes per minute (spm) from seafloor to $\sim 5 \mathrm{mbsf}$ 
before retrieving the VIT camera. After the VIT camera was recovered, bit rotation and pump rates of 50 rpm and $12 \mathrm{spm}$ were used to 25 mbsf while maintaining an ROP of $30 \mathrm{~m} / \mathrm{h}$. From 25 to $35 \mathrm{mbsf}$, pump rates were increased to $80 \mathrm{spm}$. From 35 to $247 \mathrm{mbsf}$, an ROP of $30 \mathrm{~m} / \mathrm{h}$ and pump rates of at least $80 \mathrm{spm}$ were maintained.

The GeoVision Resistivity tool had low battery power and would not record data when the pumps were turned off. At $198 \mathrm{mbsf}$, a $3 \mathrm{~m}$ thick sand layer was encountered and APWD increased by $\sim 1 \mathrm{MPa}$. A residual backpressure of $\sim 1 \mathrm{MPa}$ was also observed by the driller when the mud pumps were shut down. We pumped $10.5 \mathrm{ppg}$ mud in the hole. After a wiper trip, the overpressure stabilized and drilling operations continued. At $242 \mathrm{mbsf}$, a rapid drop in gamma radiation was observed and drilling operations were terminated to prevent penetrating an overpressured sand.

\section{Logging data quality}

Figure F2 shows the quality control logs for Hole U1323A. The target ROP of $30 \mathrm{~m} / \mathrm{h}( \pm 5 \mathrm{~m} / \mathrm{h})$ was generally achieved. The density-derived caliper $\log$ is $>24 \mathrm{~cm}$ for most of Hole U1323A, suggesting unstable borehole conditions from 0 to $130 \mathrm{mbsf}$ and from 180 to 209 mbsf. These zones had an increased bulk density correction that varied from -0.15 to $0.16 \mathrm{~g} / \mathrm{cm}^{3}$ (Fig. F2). This is greater than the larger corrections in Hole U1322A.

LWD logs were depth-shifted by identifying the gamma ray signal associated with the seafloor. The seafloor pick was $1271.1 \mathrm{mbrf}, 0.1 \mathrm{~m}$ deeper than the drillers depth. The rig floor datum was located 10.5 $\mathrm{m}$ above sea level.

\section{Annular pressure while drilling and equivalent circulating density}

Annular pressure within the borehole was monitored during MWD operations (see discussion in "Array Resistivity Compensated Tool" in "Downhole measurements" in the "Methods" chapter) as annular pressure in excess of hydrostatic (APWD*) and equivalent circulating density referenced to the seafloor $\left(\mathrm{ECD}_{\mathrm{rsf}}\right)$ (see "Downhole measurements" in the "Methods" chapter). ECD rsf $_{\text {rf }}$ decreases and APWD* increases from 0 to 150 mbsf (Fig. F3). From 150 to 198 mbsf, the $\mathrm{ECD}_{\text {rsf }} \log$ gradually increases where an overpressured silty sand interval was encountered (Fig. F3). At 198 mbsf, APWD* increased by $\sim 1 \mathrm{MPa}$ over a $3 \mathrm{~m}$ thick interval. After pumping weighted mud and running a wiper trip, drilling operations resumed. APWD* below 198 mbsf increased gradually. $\mathrm{ECD}_{\text {rs }}$ decreased gradually, showing no significant anomalies, thus suggesting that we did not drill through any additional overpressured units.

\section{Results}

LWD/MWD operations in Hole U1323A reached 247 mbsf. Hole diameter averaged $29.4 \mathrm{~cm}$ with enlarged conditions from 0 to 130 and 180 to 209 mbsf (Fig. F4). Gamma ray (GR) measurements increased with depth, averaging $~ 70$ gAPI throughout the borehole. The GR signature showed a consistent increase from the seafloor followed by a similar decrease until reaching a low at 40 mbsf. A GR decrease to $30 \mathrm{gAPI}$ indicates the presence of an overpressured sand at $\sim 198$ mbsf. At $\sim 244$ mbsf the GR values dropped to 47 gAPI, indicating the top of a second sand unit (Fig. F4).

The resistivity $\log$ showed a general increase with depth until $\sim 198$ mbsf, where a decrease in resistivity marks the top of the overpressured sand unit. Overall, resistivity ranged from 0.3 to $1.5 \Omega \mathrm{m}$ (mean $=1.1$ $\Omega \mathrm{m})$. Bulk density increased gradually with depth from 1.3 to $1.9 \mathrm{~g} / \mathrm{cm}^{3}$, corresponding to neutron porosity values ranging from $90 \%$ to $47 \%$. Photoelectric factor (PEF) values range from $2.1 \times 10^{-24}$ to $4.1 \times$ $10^{-24} \mathrm{~b} / \mathrm{e}^{-}$to a depth of 184 mbsf. Below this depth, PEF increased as a result of heavy mud in the borehole. Heavy mud containing barite was used below 198 mbsf.

\section{Interpretation of units}

The stratigraphic succession drilled at Site U1323 was divided into logging Units 1,2, and 3 based on gamma ray and resistivity logs. Logging Unit 1 is further divided into Subunits 1a, 1b, 1c, and 1d.

\section{Logging Unit 1 (0-197 mbsf)}

Logging Unit 1 is interpreted as clay with several silty intervals and two MTDs. The inferred subunits were classified using the following criteria.

\section{Subunit 1a (0-40 mbsf)}

Logging Subunit 1a extends from 0 to 40 mbsf, just below seismic Reflector S10 (Fig. F5). This subunit was defined on the basis of gamma radiation, which increases from 0 to 20 mbsf followed by a decrease until 40 mbsf. Increasing resistivity values define the base of this subunit. Subunit 1a is characterized by an alternation of low- and high-amplitude reflectors in seismic data. Subunit 1a correlates with lithostratigraphic Subunit IA at Sites U1324 and U1322. Based on the observations at Sites U1324 and U1322, this subunit is interpreted as clay with some silty intervals at the base. At Site U1322, this was inter- 
preted as a hemipelagic drape and very distal turbidites from channel-levee systems to the west.

\section{Subunit 1b (40-51 mbsf)}

Logging Subunit $1 \mathrm{~b}$ is characterized by constant gamma radiation and an increase in resistivity with two peaks corresponding to relatively high amplitude seismic reflectors within a zone of chaotic and discontinuous reflectors (Fig. F5). Based on the resistivity response and seismic character, Subunit $1 \mathrm{~b}$ is interpreted as a $10 \mathrm{~m}$ thick MTD. This interpretation is linked to Sites U1322 and U1324, where reverse/ normal faults and folds are observed in correlative sediments.

\section{Subunit 1c (51-97 mbsf)}

The base of logging Subunit 1c corresponds to regional seismic Reflector S20 (Fig. F5). The gamma ray profile is $\sim 70$ gAPI, resistivity increases steadily throughout the interval with minor variations, and seismic facies have parallel low- to medium-amplitude reflectors. Subunit $1 \mathrm{c}$ is interpreted mostly as clay and mud, based on the uniform gamma radiation and resistivity. A decrease in the gamma ray log at $\sim 58$ mbsf suggests a silt interval. In addition, this subunit has lower density than the overlying and underlying subunits (Fig. F4). This inferred subunit correlates with lithostratigraphic Subunit IC at Sites U1324 and U1322, which is composed of couplets of different-colored clay with a minor amount of silt laminae.

\section{Subunit 1d (97-195 mbsf)}

Logging Subunit $1 \mathrm{~d}$ is based on gamma ray and resistivity data that remain fairly consistent throughout this interval. The acoustic character of the subunit is transparent or chaotic, with some isolated mediumamplitude reflections and some locally subparallel reflections toward the base of the subunit. Based on these observations, Subunit 1d is interpreted as an interval of MTDs with few silt beds. The top and bottom of Subunit 1d correspond to seismic Reflectors S20 and S30.

\section{Logging Unit 2 (195-220 mbsf)}

The top of logging Unit 2 is characterized by a sharp decrease in gamma radiation from 80 to 30 gAPI and a covariant response in resistivity. These responses are interpreted as the presence of sand units (Figs. F4, F5). The top and bottom of logging Unit 2 correspond to seismic Reflectors S30 and S40-1323. Several seismic reflectors between S30 and S40-1323 are subparallel with good lateral continuity that could represent transitions from mud/clay beds to silt/ sand-rich layers. Logging Unit 2 cannot be correlated to Site U1324 or Site U1322.

\section{Logging Unit 3 (220-242 mbsf)}

Logging Unit 3 is characterized by increasing gamma radiation with depth, which suggests an increase in mud/clay content (Figs. F4, F5). Variations are observed at $\sim 224 \mathrm{mbsf}$, suggesting increased silt content and, at 242 mbsf, indicating increased sand content. The seismic data in this interval show discontinuous reflectors. The base of the unit is characterized by a high-amplitude reflector that correlates with sand at $242 \mathrm{mbsf}$.

\section{Physical properties from logging data}

LWD bulk density data were used to derive porosity (Equation 1 in the "Site U1321" chapter) (Fig. F6A). Bulk density increases gradually with depth from 1.3 to $1.9 \mathrm{~g} / \mathrm{cm}^{3}$, which corresponds to porosity from $78 \%$ to $45 \%$. The upper $40 \mathrm{~m}$ of the sequence (logging Subunit 1a) is characterized by relatively low bulk density that increases from 1.3 to $1.7 \mathrm{~g} / \mathrm{cm}^{3}$ and calculated porosity from $78 \%$ to $55 \%$ (Fig. F6A). Logging Subunit $1 \mathrm{~b}$ has small variations in bulk density and porosity. Bulk density within logging Subunit 1c gradually increases from 1.6 to $1.7 \mathrm{~g} / \mathrm{cm}^{3}$. Logging Subunit 1d, an MTD, shows increasing bulk density from 90 to 120 mbsf and constant bulk density of $1.9 \mathrm{~g} / \mathrm{cm}^{3}$ below 170 mbsf. Low density observed at 120 and 135 mbsf is attributed to large borehole diameter. The top of Subunit 1d is marked by a density increase of $0.02 \mathrm{~g} / \mathrm{cm}^{3}$, whereas at the base of the subunit bulk density drops by $\sim 0.05 \mathrm{~g} / \mathrm{cm}^{3}$ (Fig. F6A). A comparison of LWD-calculated porosity data versus hydrostatic vertical effective stress from Sites U1322, U1323, and U1324 indicates that the sedimentary sequence drilled at the three sites follows the same trend (Fig. F6C). Thus, the data suggest that the sedimentary successions at all three sites have similar consolidation states.

\section{Core-log-seismic integration}

LWD observations are linked to seismic data through a time-depth conversion using check shot data from Hole U1324A. Reflection coefficients were calculated using the LWD density data and a constant compressional wave velocity of $1600 \mathrm{~m} / \mathrm{s}$. A $150 \mathrm{~Hz}$ minimum-phase Ricker wavelet was convolved with the reflection coefficients to create the synthetic seismogram (Fig. F7). The correlation between the synthetic seismogram and the high-resolution seismic matches only in the uppermost 90 mbsf. A time-depth mismatch occurs below seismic Reflector S20, where the synthetic reflections occur shallower than the same 
events in the high-resolution three-dimensional seismic data (Fig. F7).

\section{Summary}

Site U1323 downhole measurements provide insights on lithofacies for correlation with Sites U1322 and U1324. Our preliminary interpretation allows for the following conclusions:

- Logging Unit 1 was interpreted to be a mud- and/ or clay-banded unit with intervals of silt beds and MTDs. Chaotic intervals in seismic reflection pro- files are interpreted as MTDs and intervals of continuous reflectors as clay.

- Logging Unit 2 is interpreted to contain silty beds and two sand beds, defined by low resistivity and gamma ray values. Seismic facies analysis suggests that these sands are associated with the Southwest Pass Canyon eastern levee.

- Logging Unit 3 was interpreted as a MTD with some silty sand beds.

Publication: 8 July 2006

MS 308-107 
Figure F1. Seismic strip chart for Site U1323. Projected terminal depth (TD) and TD reached by LWD/MWD drilling (Hole U1323A) are shown. SF = seafloor.

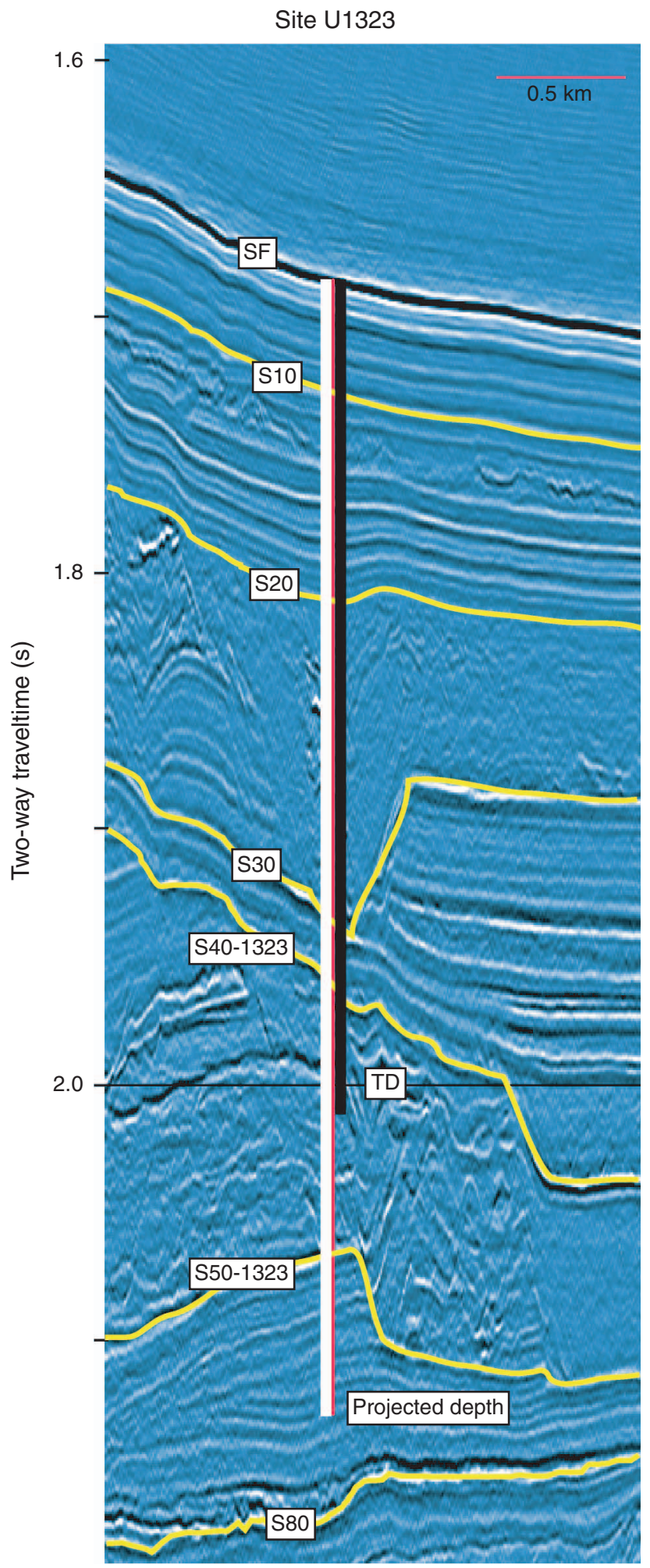


Figure F2. Data quality of curves for LWD/MWD measurements from Hole U1323A showing the rate of penetration (ROP), density-derived caliper, and density correction based on hole diameter.

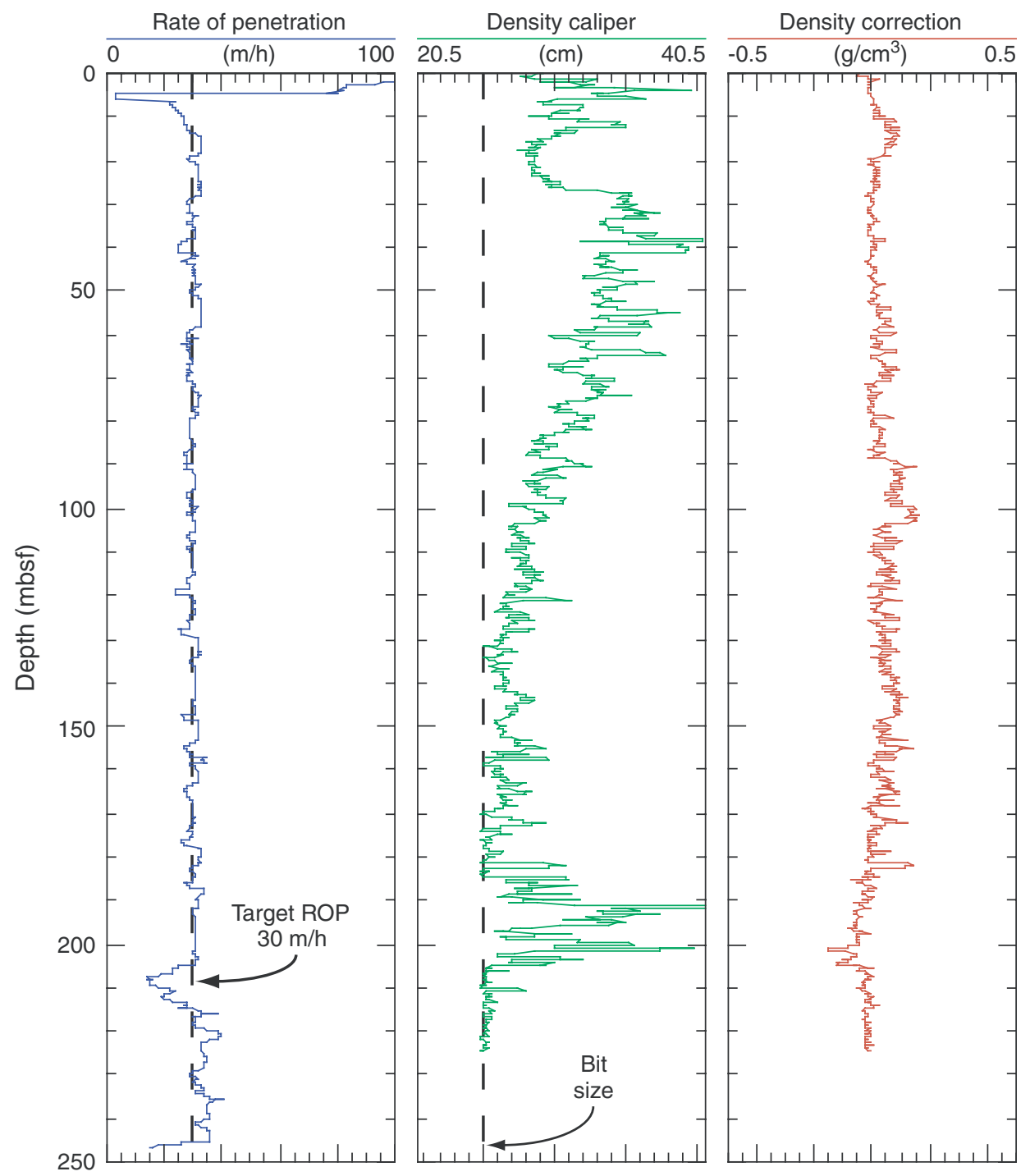


Figure F3. Annular pressure while drilling (APWD), annular pressure in excess of hydrostatic (APWD*), and equivalent circulating density referenced to the seafloor $\left(\mathrm{ECD}_{\mathrm{rss}}\right)$ in Hole U1323A. The $\mathrm{ECD}_{\mathrm{rst}}$ and $\mathrm{APWD}$ * curves decrease and increase, respectively, over the upper 150 mbsf. At 198 mbsf a $3 \mathrm{~m}$ thick sand layer recorded an increase in $\mathrm{APWD}^{*}$ of $\sim 1 \mathrm{MPa}$ over the background drilling pressure. A $10.5 \mathrm{ppg}$ mud was used for drilling below this point. $\mathrm{GR}=$ gamma radiation, $\mathrm{SF}=$ seafloor.

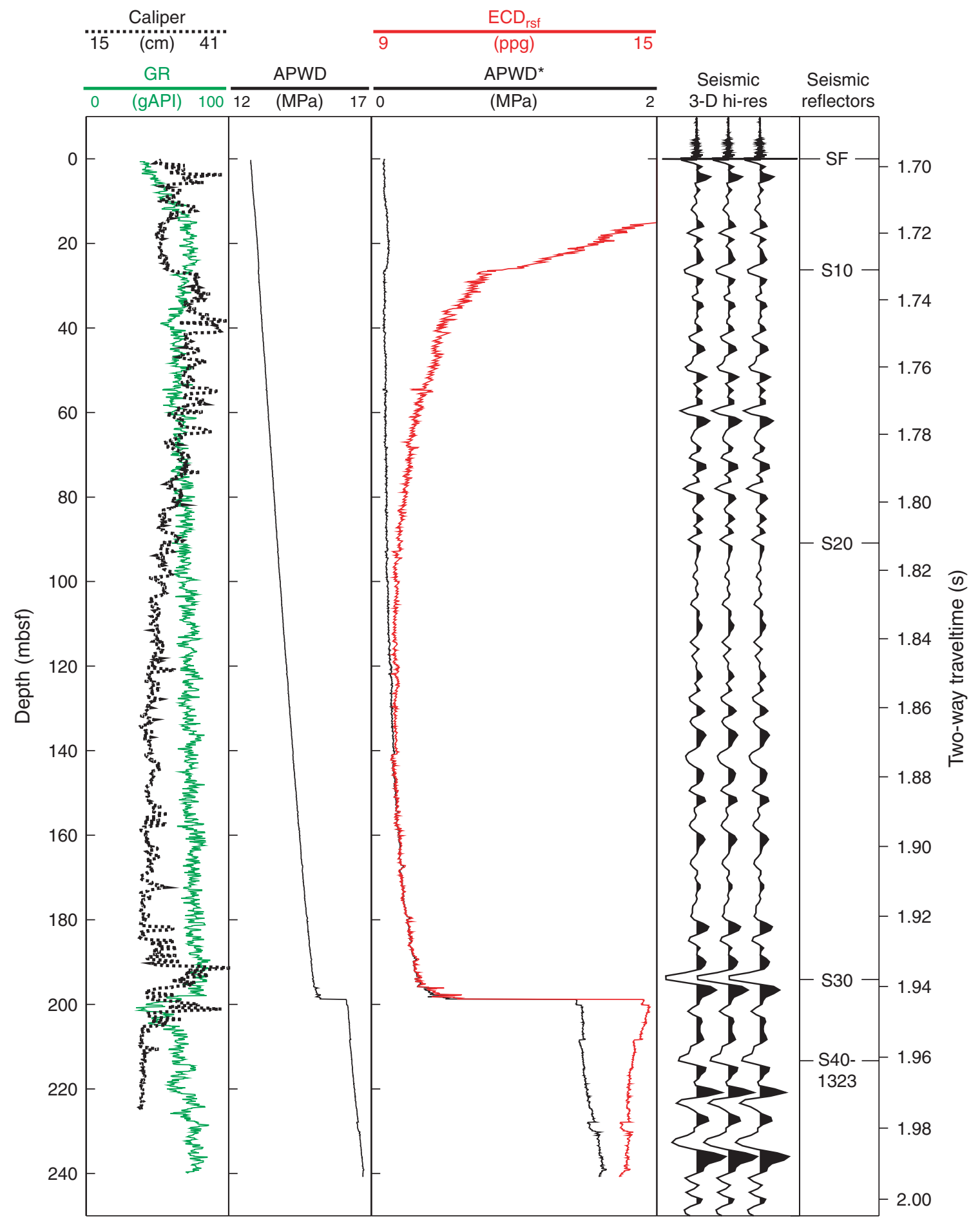


Figure F4. LWD logs recorded in Hole U1323A. Density caliper, photoelectric factor (PEF), and neutron porosity were recorded with the Vision Density Neutron (VDN) tool, whereas gamma ray and resistivity measurements were obtained with the GeoVision Resistivity (GVR) tool. Superimposed on the PEF log is a five-point average curve. Definition of units is based on gamma ray, resistivity, and seismic character. Green $=$ zones with high resistivity, yellow = low-resistivity zones. Dashed lines = depth at which $10.5 \mathrm{ppg}$ mud was used and the depth at which the VDN tool began recording heavy drilling mud flowing uphole. $\mathrm{ARC}=$ array resistivity compensated.

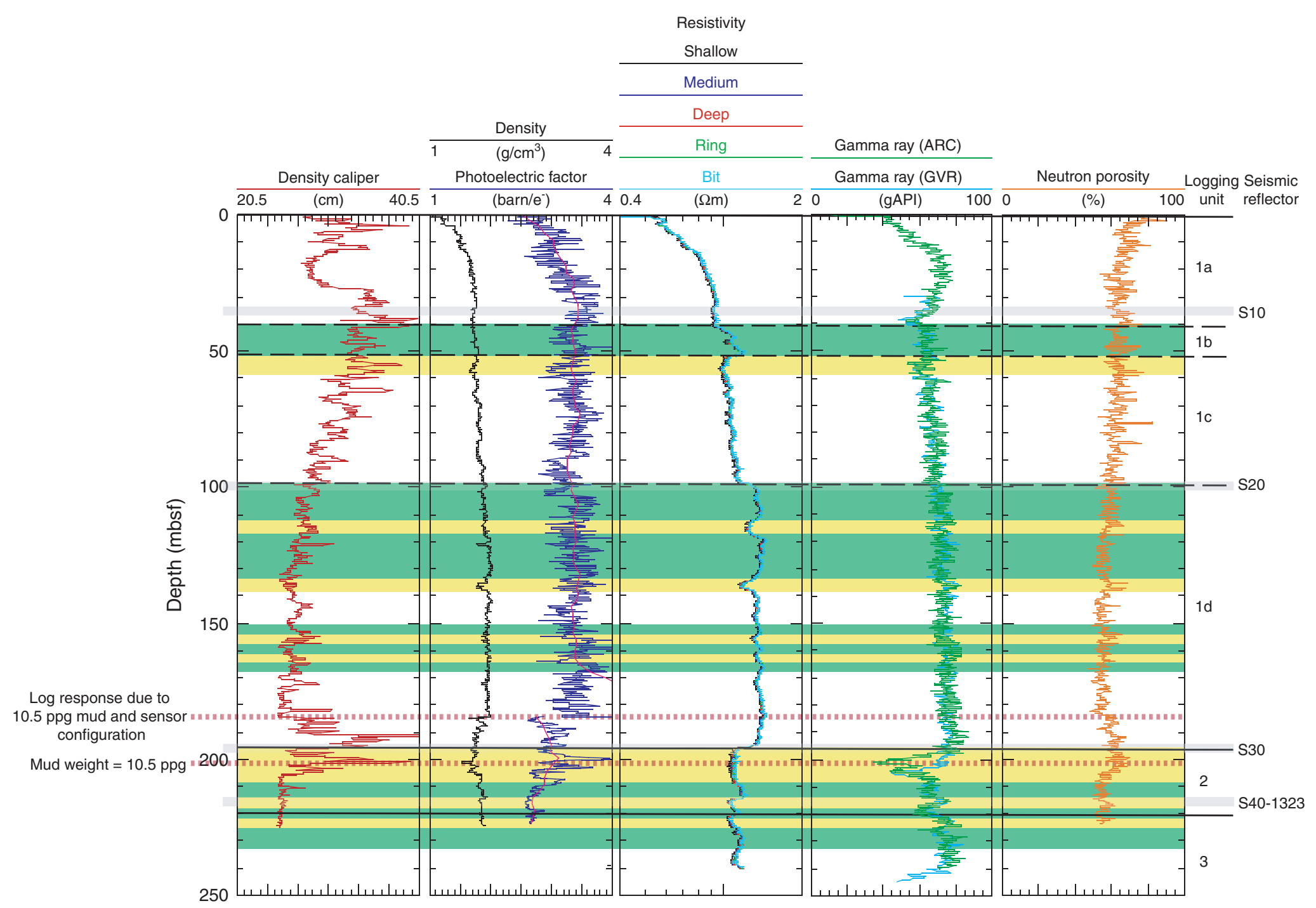


Figure F5. Seismic panel, gamma radiation, log unit/subunit divisions, inferred lithostratigraphic column, resistivity curve (log scale), and depth in two-way traveltime for Hole U1323A. The seismic panel was split at the location of Hole U1323A at trace 2170. Seismic data are approximately zero phase with black = peaks and white $=$ troughs and plotted in depth using the check shot from Hole U1324A. Key seismic reflectors are shown in yellow and labeled ( $\mathrm{SF}=$ seafloor). GVR $=$ GeoVision Resistivity, ARC $=$ array resistivity compensated.

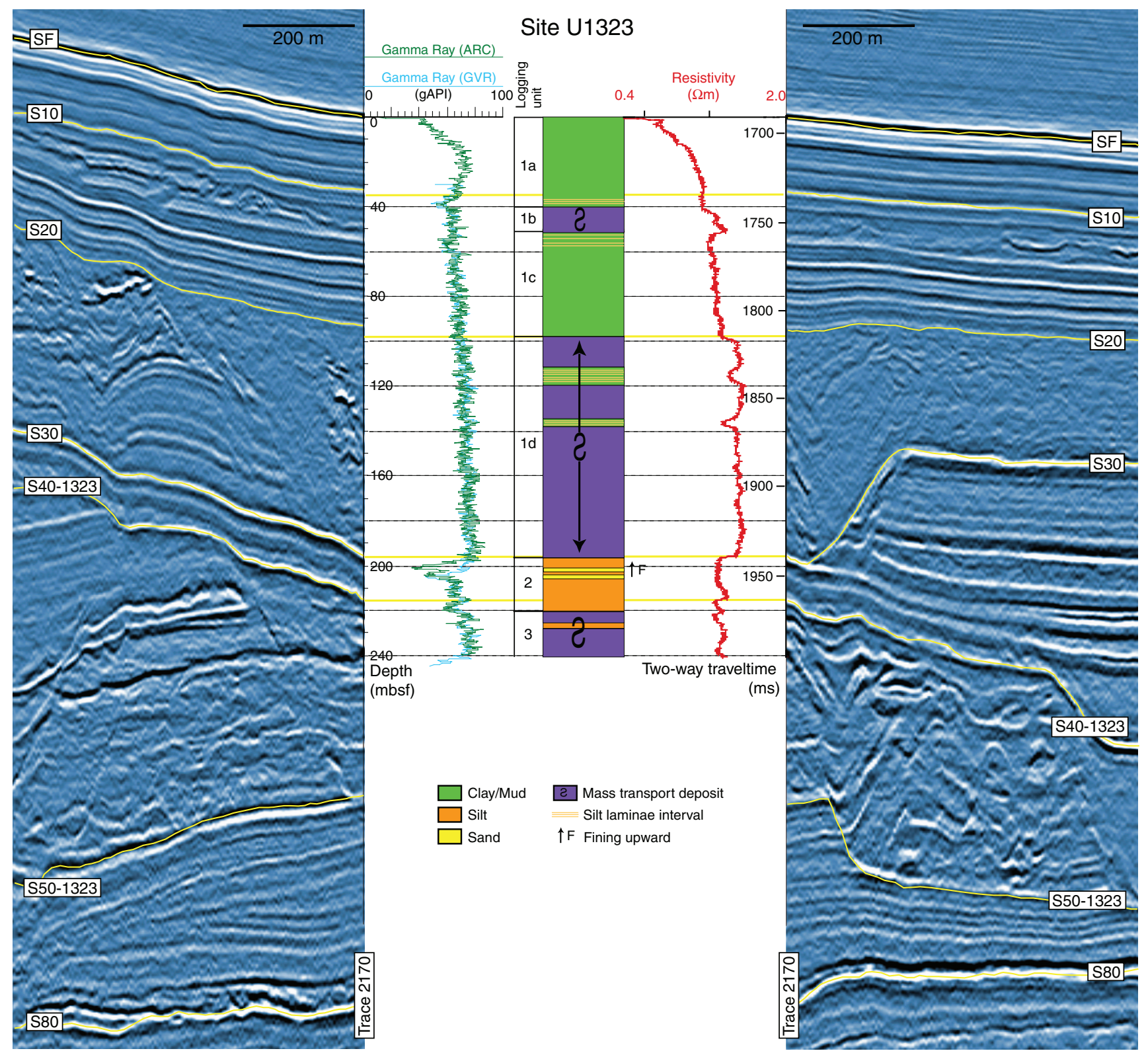


Figure F6. A. Bulk density and density-derived porosity from LWD data. B. Vertical effective stress assuming hydrostatic conditions. C. Porosity vs. vertical effective stress for hydrostatic conditions on a semilogarithimic diagram for all Ursa Basin sites.

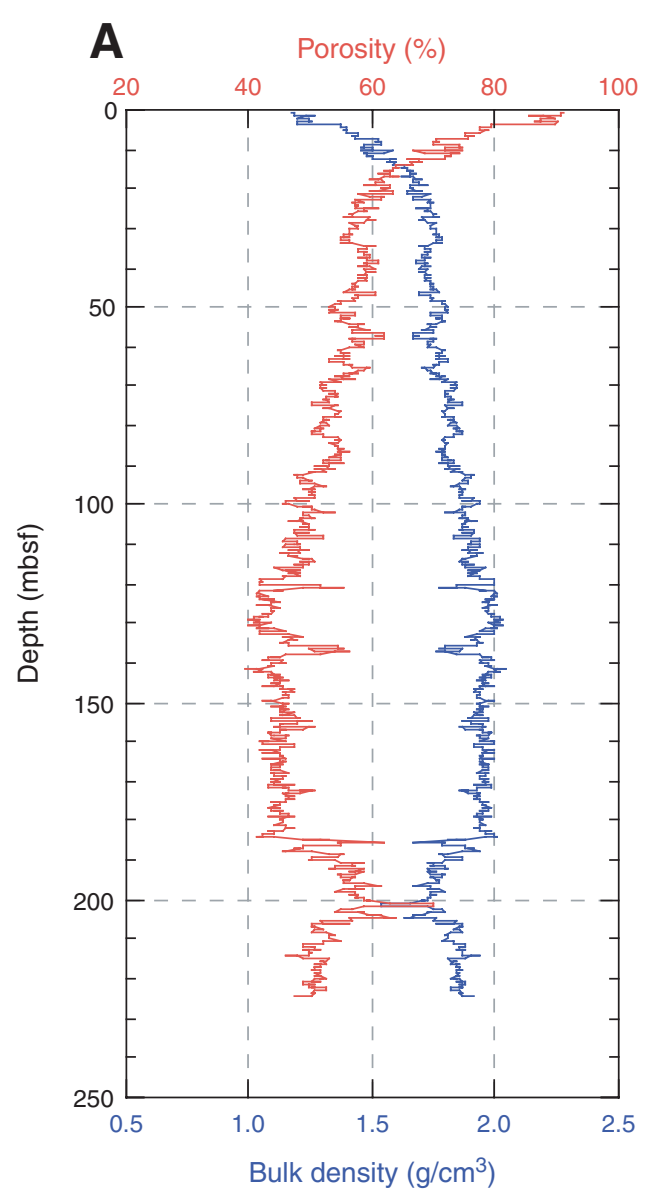

B Vertical hydrostatic effective stress (kPa)

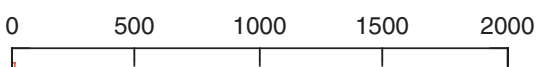

C Vertical hydrostatic effective stress $(\mathrm{kPa})$
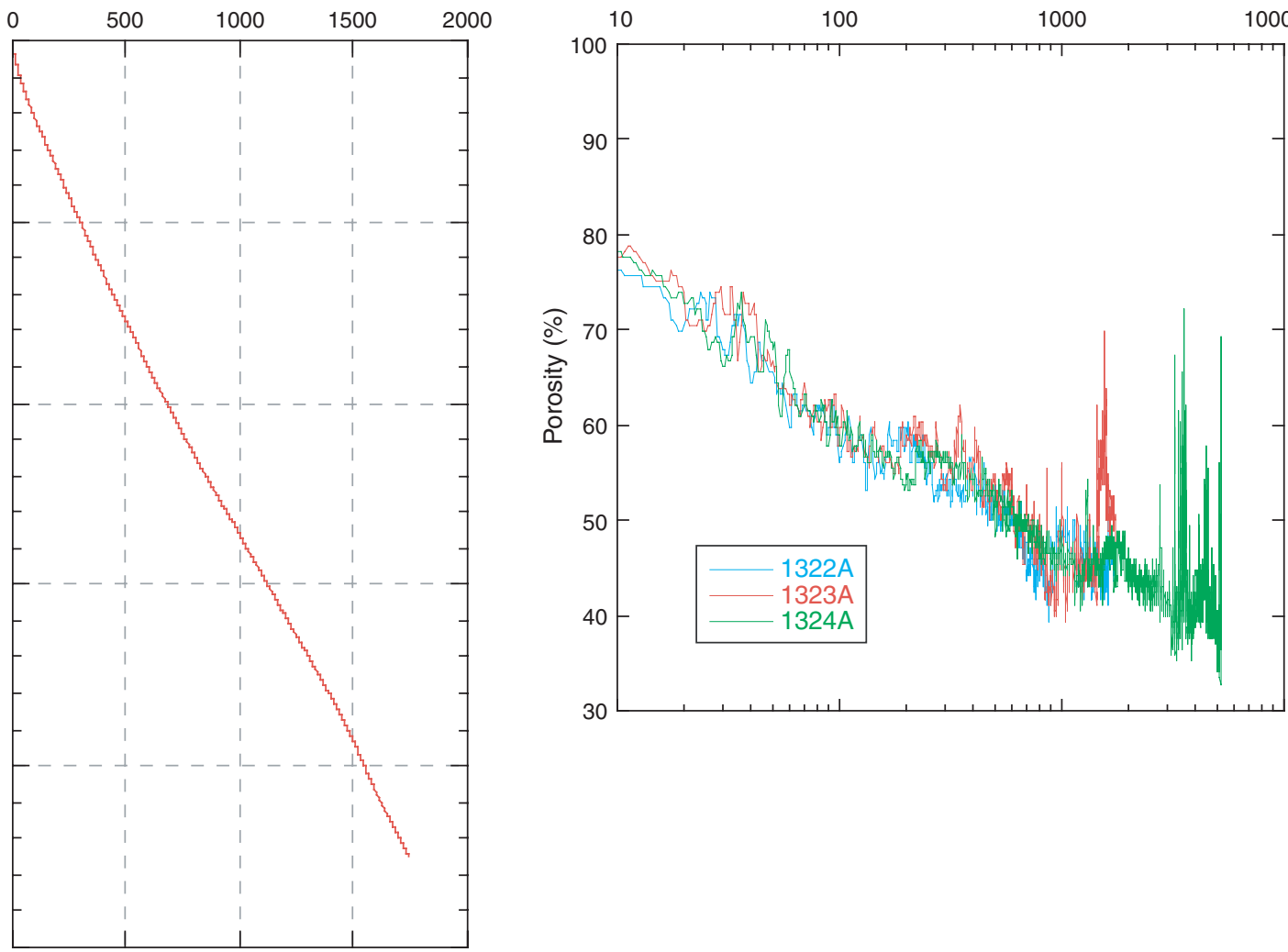
Figure F7. Log-seismic integration for Site U1323. Synthetic seismogram was constructed by convolving a 150 $\mathrm{Hz}$ minimum-phase Ricker wavelet with the reflection coefficient series based on LWD bulk density (not corrected for large washouts) and a constant velocity $(1600 \mathrm{~m} / \mathrm{s})$. A seismic high-resolution trace (Hi-Res) is extracted from 3-D high-resolution multichannel seismic data at the location of Site U1323. GR = gamma radiation, $\mathrm{SF}=$ seafloor.

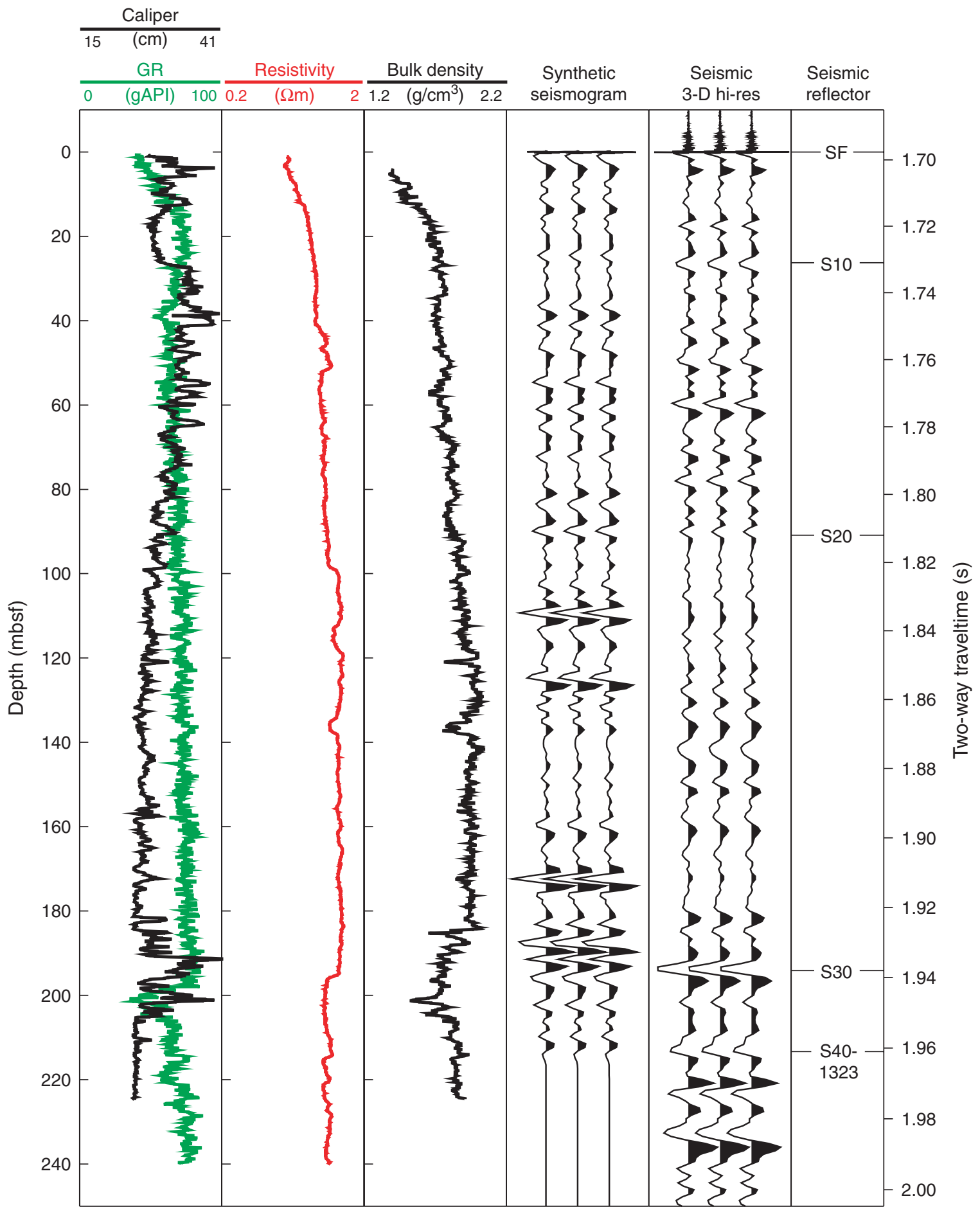


Table T1. Coring summary, Hole U1323A.

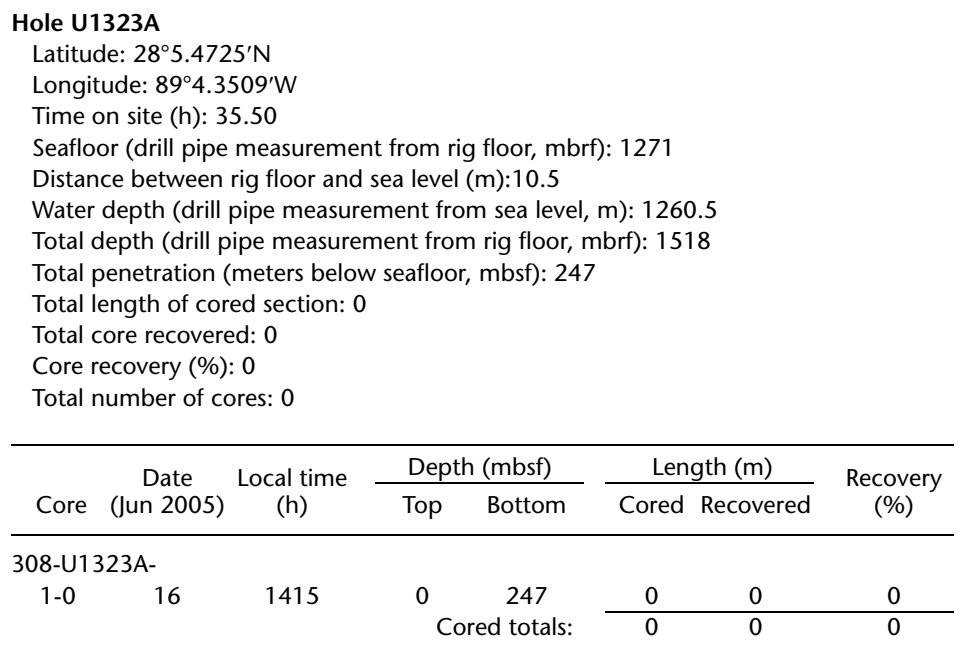

